\title{
金属繊維製造のための薄板コイル材切削 における繊維溶着現象の検討*
}

\author{
兼子正生 ${ }^{* *}$ 柳 沢 章** 中川 威 雄***
}

On Fiber Sticking Phenomenon in Coiled Sheet Shaving for Metal Fiber Production

Masao Kaneko, Akira Yanagisawa and Takeo Nakagawa

Compared to existing metal fiber production methods, coiled sheet shaving is simple and efficient. Various kind of metals can be used and fiber diameter can be easily adjusted. But one major disadvantage of the method is that fiber sticking occurs, which makes it difficult to produce fine and uniform fibers, and put the method to practical application. This investigation was conducted to clarify the causes of fiber sticking in coiled sheet shaving. Experiments were performed with metals currently used. The results showed that fiber sticking is mainly caused by metallic adhesion resulting from the heat and pressure produced during shaving. Experiments on method for reducing sticking were also performed.

Key words: metallic fiber, fiber production, sheet shaving, sticking

\section{1. 緒言}

金属材料は高分子材料あるいは無機材料と同様に，その幾何 学的形状を細径, 長尺化することで, 繊維としての特性が得ら れ, 金属繊維としてフィルタ, 吸音材および種々の用途の繊維 多孔質体の素材として，玉た機能性複合材料の混入繊維として 広く用いられている．金属を紻維化する方法としては多くのも のが提案されているが, 現在, 工業的に行われている主な方法 は引抜き法 ${ }^{1)}$, 溶融紡系法 ${ }^{2)}$, 切削法 ${ }^{3) 4}$ である。 引抜き法は細 径で均一な䋞維径のものが得られ，多くの金属材料に適用でき るが, 高コストである. 一方, 溶融紡糸法は, 適応材料が鉛や アルミニウムに限られる. また，切削法の一つであるびびり振 動切削法は，短繊維の製造に限定される．切削による長繊維の 製造法としては，コイル材切削法とワイヤ切削法があり、コイ ル材切削法は古くから提案された方法であるが5), 実際の生産 にはワイヤ切削法が用いられている。

コイル材切削法は, ワイヤ切削法に比べ, 適応材種, 䋐維径 の微細化, 均一化および材料歩どまりの点で優れていると考支 られる.しかし，この方法がほとんど活用されないのは, 繊維 製造時に切削された繊維相互に溶着が生じ, 䋐維の分離が完全 に行われず，本来製造可能な繊維径が得られないことが主な原 因である。この現象が防止できれば，コイル材切削法で，細 径, 均一でから多材種の金属繊維が低コストで得られ，広範曲 な用途の拡大が期待される.本研究は，多くの利点を持つコイ ル材切削法を工業的な金属緘維の製造法として確立することを 目的として行われた. 本報告は, 金属繊維の対象材料として考 㐫られる銅, 黄銅, アルミニウム, ステンレス鋼を用い, まず 溶着現象の把握とその解明を行い, また，いくつかの溶着防止 策の検討と, その効果の確認を行った.

\section{2.コイル材切削法と実験条件}

図 1 にコイル材切削法による金属繊維製造法を示す。この方 法は，金属薄板をコイル状に巻き，このコイル材の端面を旋削

\footnotetext{
* 原稿受付 平成 6 年 7 月 15 日

** 正会員 日本工業大学工学部（埼玉県南埼玉郡宮代町学園台 4-1）

*** 正会員 東京大学生産技術研究所 (東京都港区六本木 7-22-1)
}

加工し，金属䋐維を得るものである，この方法では，基本的に 所定のコイル材巻厚を 1 回の切込みで切削することが行われ， したがって、コイル材の板厚と巻厚で決まる本数の繊維束が得 られる. 図 2 にこの方法で得られた金属繊維の外観とその断面 形状の例を示す。断面形状は長方形をしており，その一辺はコ イル材の板厚に㟫ぼ一致し, 他の一辺は主として工具の送り量 で決まる值となる．この纎維断面の底面は工具すくい面に直接 触れている面であり，比較的平滑であるが，上面は自由生成面 であり，微細な山凸が見られる，繊維厚さは送り量より大きな

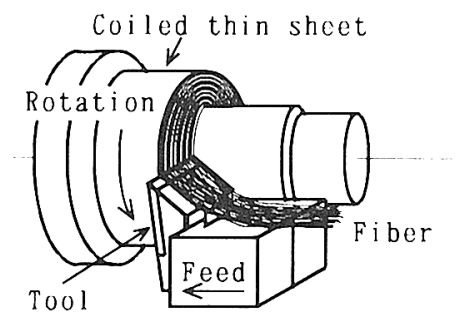

Fig. 1 Schematic illustration of the coiled sheet shaving method

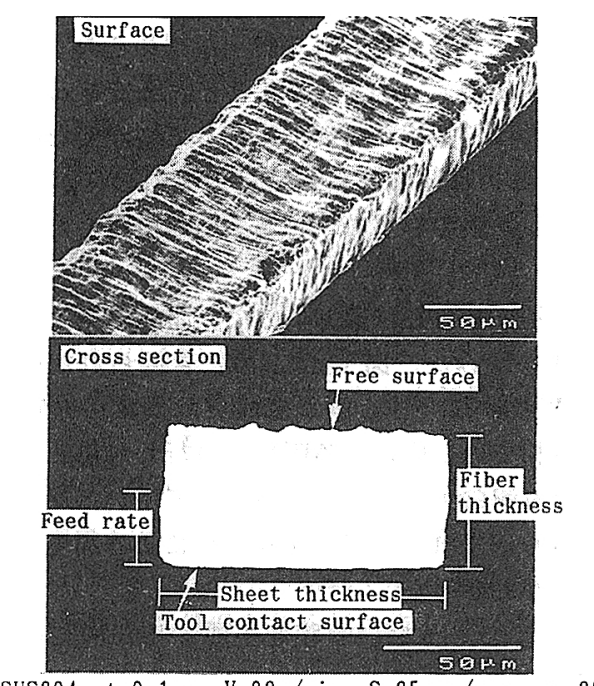

SUS304, $\mathrm{t}=0.1 \mathrm{~mm}, \quad V=82 \mathrm{~m} / \mathrm{min}, \quad S=25 \mu \mathrm{m} / \mathrm{rev}, \quad \gamma=25^{\circ}$

Fig. 2 Enlarged surface and cross section of fiber produced by coiled sheet shaving 
Table 1 Experimental conditions

\begin{tabular}{l|l}
\hline Cutting tool & $\begin{array}{l}\text { High speed steel tool } \\
\text { Sintered carbide tool (P 20) }\end{array}$ \\
\hline Cutting condition & $\begin{array}{l}\text { Rake angle } \gamma ; 20-45^{\circ} \\
\text { Back clearance angle } \alpha ; 10^{\circ} \\
\text { Approach angle } \phi ; 2^{\circ} \\
\text { Cutting speed } V ; 30-92 \mathrm{~m} / \mathrm{min} \\
\text { Feed rate } S ; 5-40 \mu \mathrm{m} / \mathrm{rev} \\
\text { Width of cut } W ; 20 \mathrm{~mm} \\
\text { Coolant for SUS } ; \text { Water soluble coolant } \\
\end{array}$ \\
\hline Work material (JIS) & $\begin{array}{l}\text { Stainless steel (SUS 430, SUS 304) } \\
\text { Copper (C 1020 R-H) } \\
\text { Brass (C 2680 R-1/2 H) } \\
\text { Aluminum, and alloy (AIN 30-O, A 5052) }\end{array}$ \\
\hline Sheet thickness & $t=0.1,0.05, \quad(0.01) \mathrm{mm}$ \\
\hline
\end{tabular}

值となるが，これはせん断角によって決まり，切削条件によっ て変化蛮る。両側面はコイル材の王延面であり，溶着現象は隣 接寸る織維の压延面の上下角部で生じている.

供試材としてはステンレス鋼（SUS 304, SUS 430), 銅 (無酸素銅), 黄銅 (Cu65-Zn35), アルミニウム（純アルミニ ウム, $\mathrm{Al}-\mathrm{Mg}$ 合金) の板厚 $0.05,0.1 \mathrm{~mm}$ のもの用い， ス テンレス鋼は超硬工具を用いた湿式切削，その他の供試材は高 速度工具鋼を用いて乾式切削を行った。これらの切削条件等を まとめたものを表 1 亿示す。

実験装置は普通旋盤の主軸チャック部を取り外し，新たに巻 付け軸を取り付けたものを用いた，巻付け軸は直径 $150 \mathrm{~mm}$, またコイル材の巻厚は $20 \mathrm{~mm}$ とした。したがって，切削速度 はコイル材の内周と外周とで士13\% 程度の差異を生ずるが, これらの平均值すなわち巻厚中央部での值を用いた。薄板の巻 付けは旋盤の回転によって行らが，適正な巻付張力を得るため のブレーキ装置をコイル素材支持軸に取り付けた．巻付張力が 不十分であると切削時に金属薄板の層間での変形，外周でのめ くれが生じるので，それを防止する条件を調べ，材質，板厚に 応じて約 $100 \sim 200 \mathrm{~N} \cdot \mathrm{m}$ の範囲でブレーキトルクを变点コイル 材の巻付けを行った。

\section{3. 切削実験と溶着現象}

\section{1 各材種の切削実験}

まず，板厚 $0.1 \mathrm{~mm}$ の各材種を用い，溶着の少ない緎維がぞ の上うな条件で得られるかを調べた。切削速度とすくい角を变 化させ，目視にて溶着が最も少ないと思われる条件を求めた。

各材種の生成繊維は, いずれも単一緎維と溶着緎維の混在し たものとなり，黄銅では比較的溶着現象の少ない条件が得られ たが，銅，アルミニウム合金は，黄銅よりやや大きな溶着を示 し，純アルミニウムはさらに溶着の少ない条件を求めることが 困難であった。とくにステンレス鋼では，湿式切削にもかかお らず，溶着を低減させることが困難で，繊維としての形態が得 にくいことが確認でさた。図 3 は溶着の最も少なかった切削条 件で得られた繊維の外観とその断面を示したるのである.

この繊維溶着の程度を定量的に確認するため繊維溶着率 $R_{\mathrm{s}}$ を，本来生成されるべき繊維本数（コイル材巻数に相当）を $N$, 実際に生成された䋐維本数を $n$ とした時, $R_{\mathrm{s}}=\{(N-n)\}$ $N\} \times 100(\%)$ と定義し，测定した．図 4 亿前述の実験で得ら れた各繊維の溶着率の測定結果を示す，溶着率は比較的大きな ばらつきを示すが，その平均値は目視の結果とほぼ一致し，黄

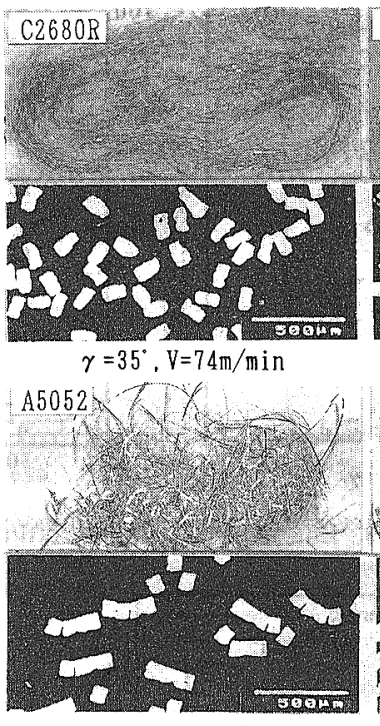

$\gamma=45^{\circ}, V=60 \mathrm{~m} / \mathrm{min}$

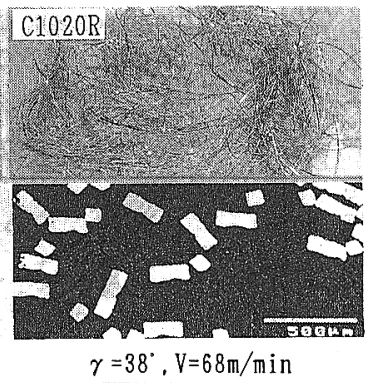

$\gamma=38^{\circ}, V=68 \mathrm{~m} / \mathrm{min}$

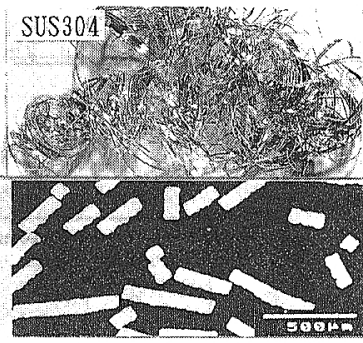

$\gamma=25^{\circ}, \mathrm{V}=82 \mathrm{~m} / \mathrm{min}$ $\mathrm{t}=0.1 \mathrm{~mm}, \mathrm{~S}=20 \mu \mathrm{m} / \mathrm{rev}$

Fig. 3 General view and cross section of metal fibers produced in the optimal conditions

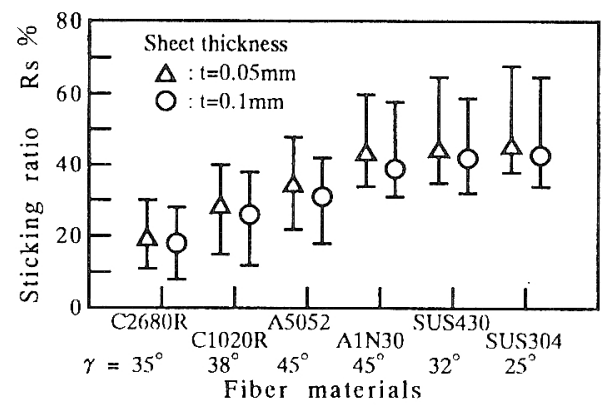

Fig. 4 Fiber sticking ratio of different kinds of metal fibers

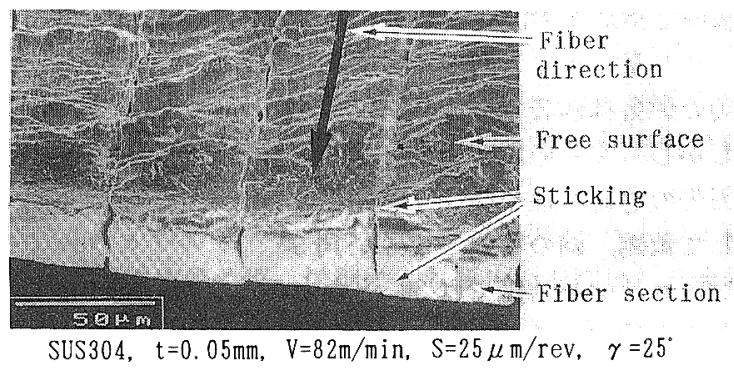

Fig. 5 Appearance of fiber sticking

銅，銅の場合に蚲平均約 $18 \% ， 26 \%$ と少なく，ステンレス鋼 は 43\% 程度と大きな值となった。純アルミニウムはステンレ ス鋼に次ぐ大きな值を，アルミニウム合金はこの中間の值を示 した. ステンレス鋼の場合, 工具寿命の点から SUS 304 では すくい角を $25^{\circ}$, SUS 430 では $32^{\circ}$ と他の材種に比べ，小さく する必要があり，このことも溶着率が大きくなった一因と考党 られる.さらに, この汪かニッケル, チタン, 八ステロイ等の 材種についても同様の実験を行ったが, 繊維溶着率はステンレ ス鋼と同様に $40 \%$ 以上と大きく，溶着の少ない繊維の製造が 困難であった。

図 5 に溶着繊維の自由生成面之断面の例を示す。溶着断面の 観察から，溶着は繊維の長方形断面の上下角部で生じている. このことから, 溶着は切削による板厚方向の変形々, その時の 温度条件が基本的な要因と考兄られ，溶着率の差異は，材種の 

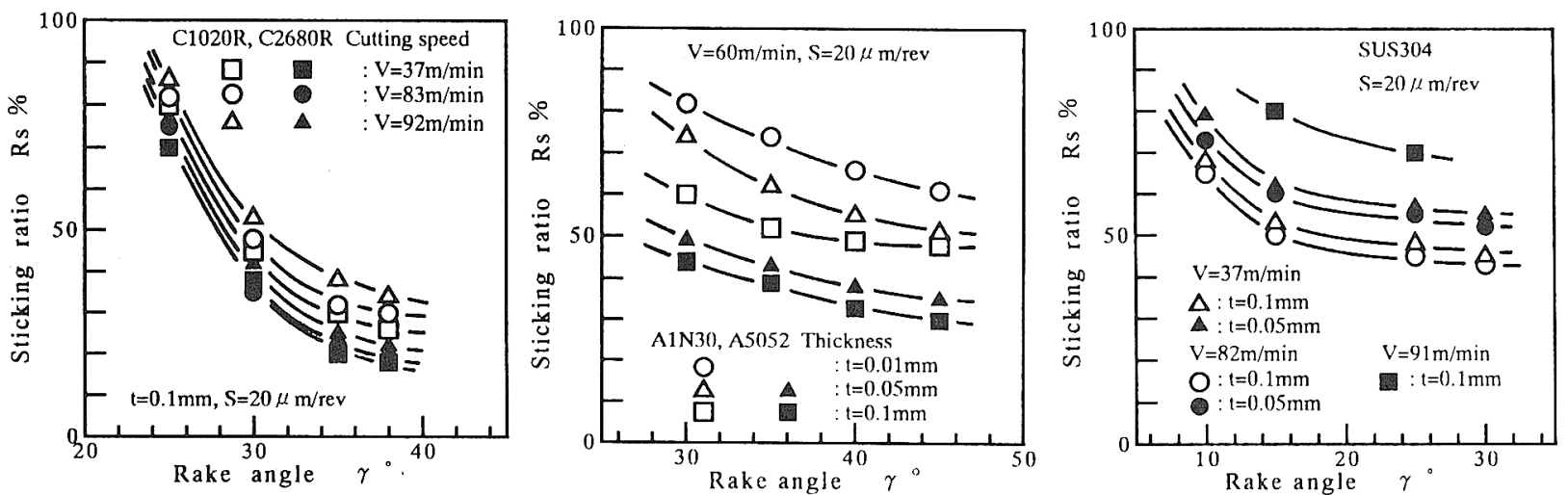

Fig. 6 Effects of rake angle, cutting speed, and sheet thickness on fiber sticking ratio

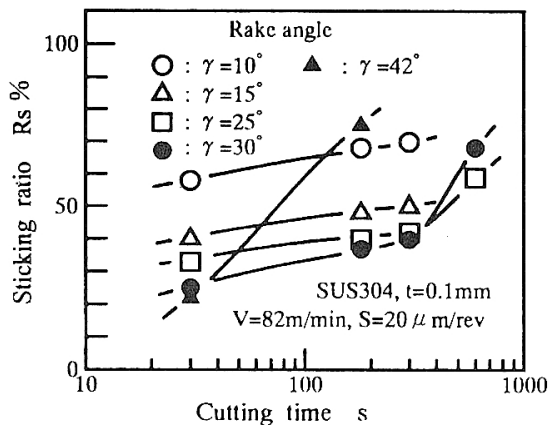

Fig. 7 Relation between sticking ratio and cutting time

展延性の違いによる变形の大小，材種による凝着力の大小，熱 伝導率の差異による温度上昇の違いなどが相互に影響している と考克られる。ぬた，溶着は工具接触面側に比べ自由生成面側 により多く発生することが確認された。

\section{2 切削条件と溶着現象}

ここでは，各材種を用い，工具すくい角，切削速度拉よび板 厚の变化が溶着率に与克る影響を検討した。すくい角，切削速 度，板厚之溶着率の関係を図 6 に示す。切削条件のうち，すく い角，送り量は板厚方向の変形に関与すると考光られるが，す くい角の影響は顕著で，すくい角が大きい程，溶着率は減少す る.しかし，すくい角を過大にすると，刃物角が小さくなるた め，刃先の急速摩耗やびびりが発生する，最も溶着率の低い条

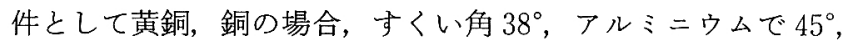
SUS 304 ステンレス鋼では $30^{\circ}$ となった。 また，同一すくい角 で溶着率を比較すると，例学ば $30^{\circ}$ では，純アルミニウムが最 も高い值を示し，ステンレス鋼，アルミニウム合金，銅はほほ 同じ值，黄銅は最も低い值となった。これは材種による溶着傾 向の差異を示していると思われる。

図 7 にSUS 304 ステンレス鋼のすくい角を変化させた場合 の，切削時間の経過と溶着率の変化の関係を示す。すくい角を $42^{\circ}$ と大きくすると，切削の経過と共に切れ刃摩耗が短時間で 進行し，溶着現象の急邀な増加が見られる。また，ステンレス 鋼以外の材種では，アルミニウムでは $55^{\circ}$, 銅, 黄銅では $42^{\circ}$ でびびりが発生し，繊維の切断が生じた，切削速度の溶着率に 与える影響は必ずしも顕著ではないが，ステンレス鋼に扣いて は切削速度が $91 \mathrm{~m} / \mathrm{min}$ の場合，溶着率が大きく増加してい る.これは切削速度の上昇による，発熱量の増加が主な原因々 考えられる．また，板厚が減少すると溶着率が増加することが 確認され，特にアルミニウムでその傾向は顕著に認められた． これは板厚が小さい場合, 生成寸る繊維は細径となり, 繊維の 剛性が低下するため，わずかな溶着力でも分離し難くなるため

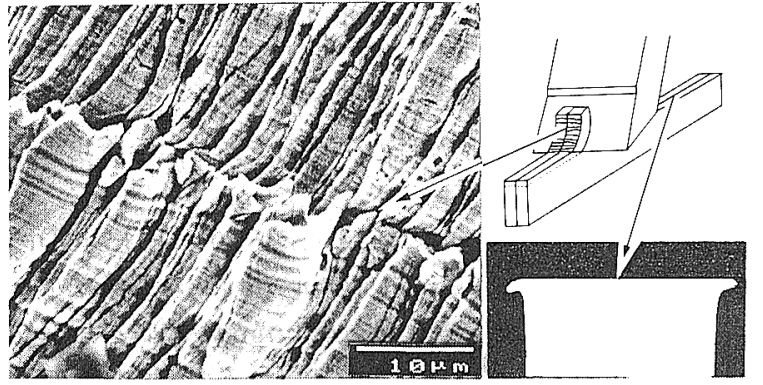

Free surface of chips Cross section of sheets Material: Copper, $\mathrm{t}=2 \mathrm{~mm}, \mathrm{~V}=62 \mathrm{~m} / \mathrm{min}, \gamma=25^{\circ}$, Depth of cut: $50 \mu \mathrm{m}$ Number of cut: 5 times

Fig. 8 Sticking at boundary of sheets

と考えられる。この伍か，送り量の影響についても調べたが， 工具送り量の増加と共に溶着率はわずかに増加するものの，実 験の範用内ではその影響は大きくはなかった。

\section{4. 綫維溶着要因の検討}

\section{1 積層板切刿による加圧力の発生}

コイル材切削法の特徵的な条件は薄板の緊密な積層状態によ る切削であることから，積層板切削によって生じる板材の境界 面がぞのような状態になるかを観察した。図 8 は厚さ $2 \mathrm{~mm} の$ 銅板を 2 枚重水，守くい角 $25^{\circ}$ ，切込及 $50 \mu \mathrm{m}$ ，切削速度 62 $\mathrm{m} / \mathrm{min}$ で，長手方向に 5 回の繰返し切削により生じた板厚方 向への幅広がりと，切りくずの自由生成面の境界部を示したも のである. 拘束されない両外側では当然自由な幅広がりを生じ るが，板厚境界部分では材料相互の拘束により幅広がりが生じ ない，このため，拘束される境界部分では板材に圧縮応力が作 用している.この幅広がりはすくい角が小さい程大きくなり， より大きな応力が発生し，溶着の主因をなすと考占られる。こ の溶着は切削による新生面が生じる上下角部すなわち工具逃げ 面側（次工程での切りくず自由生成面側）と工具すくい面側の 2 か所に発生し，材料相互の拘束力の大きな逃げ面側がより大

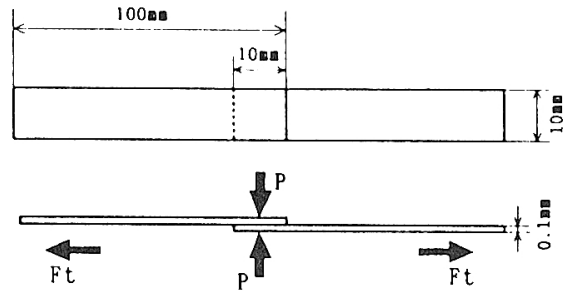

Fig. 9 Specimen for adhesion test 

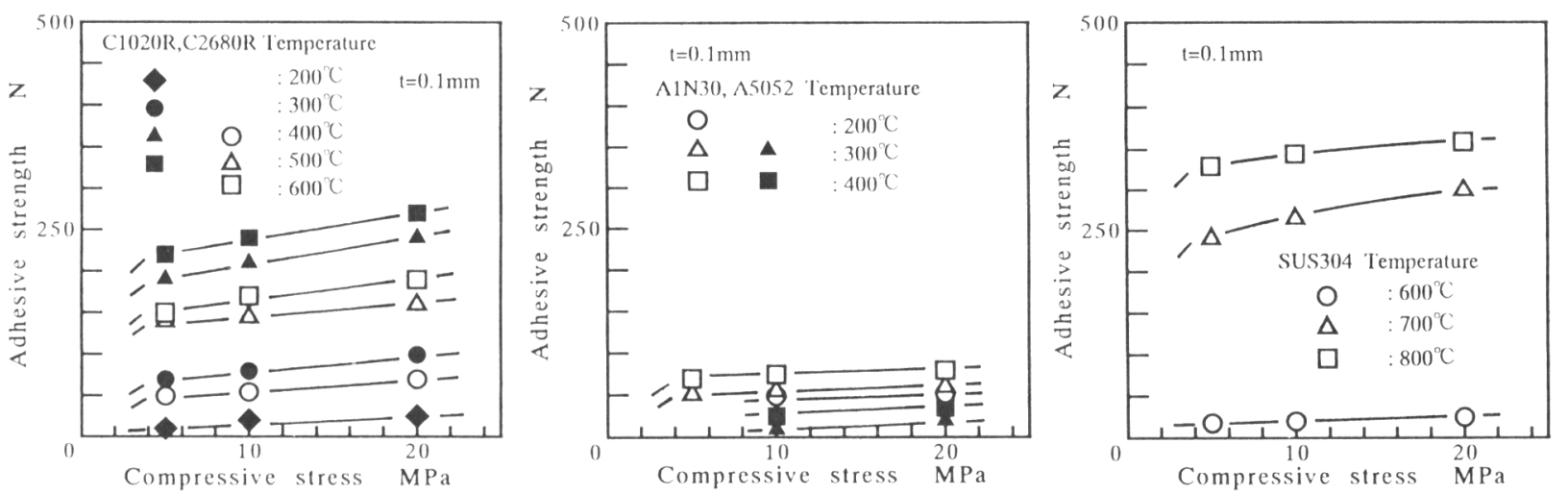

Fig. 10 Effects of compressive force and temperature on adhesive strength

きい。さらに，切りくず自由生成面側では境界部に幅方向の塑 性変形による凹凸が認められ，この変形部分にはわずかな相互 すべりが生じているはずであり，これも溶着を助長すると考光 られる。これらの現象が溶着の要因となり，交た，工具接触面 より，自由生成面の溶着が生じやすい原因となっていると考光 られる。

\section{2 被削材温度上昇の影響}

繊維溶着現象と被削材温度上昇の関係を調べるために, 薄板 材の加熱加生による接合実験を行い，その接合部の強度測定を 行った，接合実験は図 9 に示すように $10 \times 100 \times 0.1 \mathrm{~mm}$ の 2 枚の薄板を $10 \mathrm{~mm}$ 重妏，ホットプレスで 30 秒間加圧し，接合 した部分を図中矢印方向に引き剥がすに要する力 $F_{\mathrm{t}}$ を測定し た.

各材種の接合強度の測定結果を図 10 に示す。各材種とも加 圧力により接合強度はわずかに増加するが，加圧力よりも加熱 温度の影響を大きく受け，温度の上昇と共に接合力は大きくな る. 加圧力 $5 \mathrm{MPa}$ に打いて銅の場合, 温度 $200^{\circ} \mathrm{C}$, 黄銅では $400^{\circ} \mathrm{C}$, ステンレス鋼では $600^{\circ} \mathrm{C}$ から接合力が発現し，銅では $300^{\circ} \mathrm{C}$ 以上，黄銅は $500^{\circ} \mathrm{C}$ 以上，ステンレス鋼（SUS 304）で は $700^{\circ} \mathrm{C}$ 以上で接合強度の著しい増加が見られた。また，ア ルミニウムの場合, 他の材種に比較して接合強度は低い值で

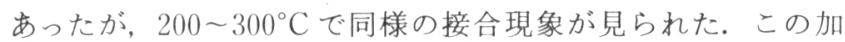
熱加压による接合現象は，加熱加圧による延性の向上と金属接 触の増加, 温度上昇による材料相互の凝着力の増加によるも $の^{6)}$ と思われるが，加厈下で比較的低温の加熱条件でも接合力 が発生することが確認された。

次に実際のコイル材切削を行って被削材温度上昇による瀻維 溶着率の変化について調べた。コイル材板厚 $0.1 \mathrm{~mm}$ を用い, 切削による邓先部温度の上昇を極力抑えるために切削速度を 2 $\mathrm{m} / \mathrm{min}$ と低速とし, 送り量は $20 \mu \mathrm{m} / \mathrm{rev}$ 一定とした。この央 験では, あらかじめ卷付け軸に巻いたコイル材を電気炉を用い て加熱し，所定温度で 30 分間保持したものを旋盤チャックに 取り付け, 接触式表面温度計で被削材温度を測定した後切削を



Fig. 11 Relation between sticking ratio and material temperature

行った.

各材種の切削温度による溶着率の变化を図 11 に，また図 12 に銅の溶着状態の变化を示す．銅の場合 $150^{\circ} \mathrm{C}$, 黄銅で 200 ${ }^{\circ} \mathrm{C}$, アルミニウムでは $70^{\circ} \mathrm{C}, \operatorname{SUS} 304$ ステンレス鋼では 700 ${ }^{\circ} \mathrm{C}$ 以上になると溶着現象が急激に顕著になり, 数本から数十 本の纎維が溶着した幅広い切りくずとなり, 繊維としての形態 が得られないことが確認できた。これらの温度值はステンレス 鋼を除いて, 前述の圧接実験結果に比較して低い値となってい るが，圧接実験では接合に新生面が関与していないのに対し て, 実際の切削実験では新生面が溶着に関与しているためと考 壳られる。これらのことから、コイル材切削法に打ける㵶維の 溶着は, 瀻維生成の際, 切削により新生面を露出した金属接触 が生じ，さらに幅広がり拘束による加圧力と切削による温度上 昇により金属接合現象が生じることが主な要因で，この活か， 自由生成面の繊維境界部での板厚方向の凹凸状塑性変形による 機械的絡みあいが寄与しているものと思われる.

\section{5. 溶着回避の条件}

\section{1 低温切削の効果}

溶着現象を回避するためには, 切削時に発生する繊維間の加
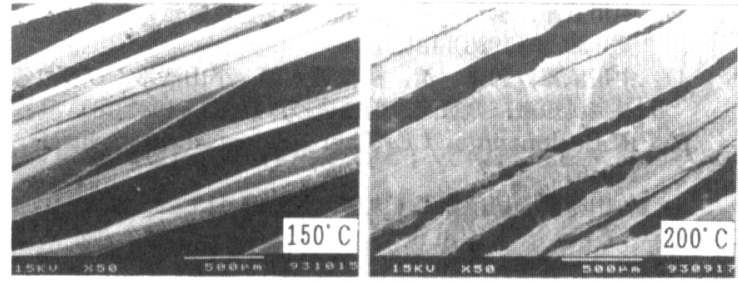

Material: Copper, $\mathrm{t}=0.1 \mathrm{~mm}, \quad \mathrm{~V}=2 \mathrm{~m} / \mathrm{min}, \quad \mathrm{S}=20 \mu \mathrm{m} / \mathrm{rev}$

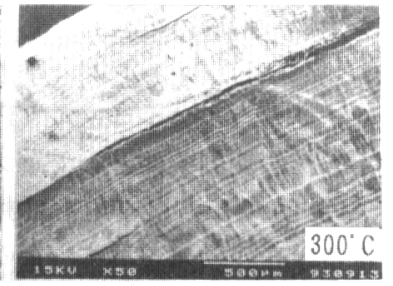

$250 \mathrm{C}$

Fig. 12 Variation of fiber sticking under different material temperatures 


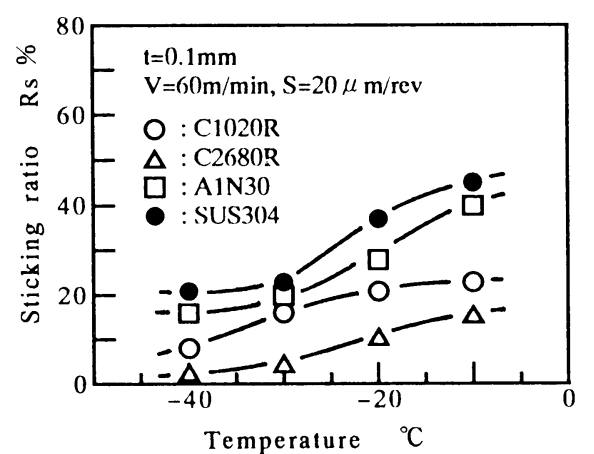

Fig. 13 Sticking ratio of low temperature shaving

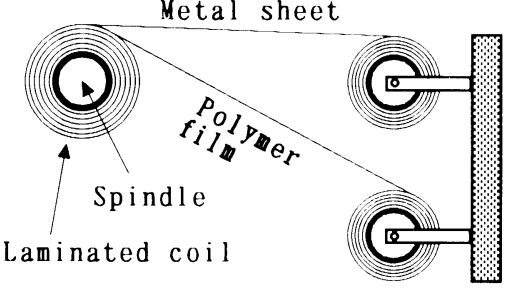

Fig. 14 Coil winding of polymer film laminated sheet

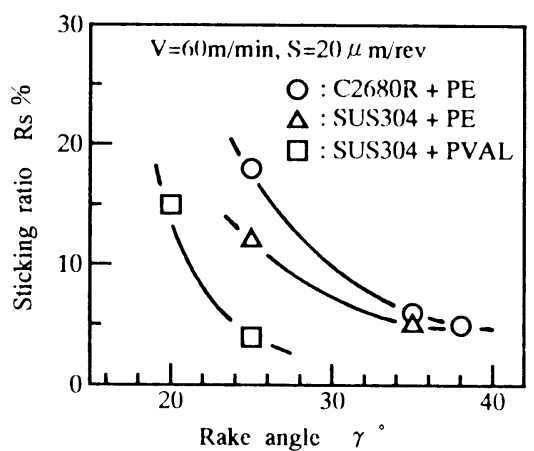

Fig. 15 Sticking ratio of metal fibers produced by polymer film laminated coil
圧力と発熱を減らし，かつ緘維間を油膜等で隔離する対策を取 ることが有効と考号られる.このうち加圧力は切削条件で決衣 り，ある程度避け得ないと考えられるので，ここではその他の 対策を検討することとした。

切削時の被削材温度が板相互の溶着現象に顕著に影響するこ とから，ここでは切削中の刃先近傍の温度上昇を極力抑えるた めに被削材を冷却し, 低温切削を行って, 瀻維相互の溶着現象 が低減する度合いの確認を行った．被削材は前述の高温実験之 同様，あらかじめコイル材を巻付け軸に巻き，液体窒素で 30 分ほど冷却したものを旋盤チャックに取り付けた。 このとき， $\mathrm{CA}$ 熱電対を巻厚中央部に巻き込及被削村温度を測定し, 所定 の温度になった後切削した. 図 13 に被削材の温度と溶着率の 関係を示す。低温切削による溶着現象の低減が著しく, 被削材 温度が $-40^{\circ} \mathrm{C}$ において, SUS 304 では約 $21 \%$, 銅で約 $8 \%$, 黄銅で約 $2 \%$, アルミニウムでは約 16\% まで溶着率が低下し た.

\section{2 油膜介在の効果}

切削油剂の介在は，薄板間を油膜で隔離すると共に，冷却作 用と潤滑作用により溶着防止の働きを持っていると考えられ る. 溶着回避を目的として, 薄板に不水溶性切削油剤である不 活性形切削油 (塩素系極圧添加剂配合, Mobil, VACMUL B 2）を塗布したコイル材を用い, 繊維製造実験を行った. そ の結果, 溶着率はアルミニウムで約 38\%, 銅で約 $20 \%$, 黄銅 で約 $12 \%$ ，ステンレス鋼で $41 \%$ とわずか 2 ス\% 減少するの みであった. この理由は巻付け張力により油剤が排除され, 残 存油膜が薄くなり, 溶着が生じる切削時の金属接触面に切削油 剂が流れ込及難いことによっていると考えられる，また，この 方法では粘度の高い切削油剂を用いる必要が生じるが，このこ とは逆に教細な繊維に付着した切削油剤の除去が困難であると いう実用上の欠点も認められた。

\section{3 プラスチックフィルム介在の効果}

次に，金属薄板の層間にプラスチックフィルムを積層し，金 属緘維相互の溶着現象の低減の効果について検討を行った. 図 14 にプラスチック積層方法を示す. 板厚 $0.1 \mathrm{~mm}$ の黄銅, ス テンレス鋼を用い，積層の組合せとしては黄銅，ステンレス鋼 とポリエチレン (PE) フィルム (厚さ $0.03 \mathrm{~mm}$ ), ステンレ ス鋼と水溶性ポリビニルアルュール $(\mathrm{PVAL})$ フィルム（厚さ $0.03 \mathrm{~mm}$ ）とした. 切削条件として，プラスチックと金属が共 に繊維形状の得られるすくい角を採用した。 図 15 にプラス チックフィルム介在の効果を示す．どの組合せでも溶着現象は 大幅に低下し，プラスチックと金属の纎維が均一に混合した繊 維束が得られた. プラスチックを膜材とした場合, プラスチッ
クの厚みが $0.03 \mathrm{~mm}$ と薄い場合でも溶着率を 3 8\% をで低減 できた。

前述の切削油剂のような流動性のある介在物では，溶着防止 効果はほとんど得られなかったが，プラスチックのような固体 膜材の介在により繊維の溶着を著しく防止できる効果のあるこ とが確認された。これはフィルムの厚さに相当するすきまが切 削時にも維持されるため, 切削による材料の幅広がりで生ずる 薄板相互の接触, あるいは自由生成面形成時の金属接触が生じ ないためであると思われる．特にPVALフィルムは水溶性を 利用して除去することが可能であることが確認され，実用的に も有効な方法であると思われる。

\section{6. 結 言}

金属薄板をコイル状に巻き，その端面を旋削加工することに より金属瀻維を得るコイル材切削法に打いて，各材種による織 維製造実験を行い繊維相互の溶着現象を調べた。 また，溶着の 要因を実験的に確認し，その防止法を検討した。得られた結果 は以下の通りである.

（1）材種によって繊維相互の溶着率は大きく異なり，銅， 黄銅では 20～25\%であるが，純アルミニウム，ステンレ ス鋼では $45 \%$ と大きくなる.

（2）溶着率は工具すくい角の影響を大きく受け，すくい角 を大きくすると溶着率が減少する.

（3）板厚は小である程溶着が多いが，切削速度，送り量の 溶着への影響は少ない。

（4）溶着現象は幅広がり拘束による王縮応力下の, 温度の 上昇による新生面の金属接合現象である.

（5）プラスチック分離膜の介在により溶着は回避可能であ る.

\section{参 考 文 献}

1）渡辺輝夫：ステンレス鋼極細線の引き拔き，塑性と加工，19, 211 (1978) 692

2）幸田成康：融放から直接フィラメントを作る話，金属，50，5（1980）

3）中川威雄，柳沢 章，鈴木 清：金属瀻維の製造と応用，瀻維と工 業, 39, 4 (1983) 121 .

4）中川威雄，鈴木 清，植松哲太郎，小山浩幸：びびり振動切削によ る金属短纎維の製造, 精密機械, 17, 11 (1981) 85.

5) R. Bachmann and E. Thur : Patentschrift, Schweiz, No. 251460, (1946).

6）竹山秀彦：切削加工，丸善，(1989）113. 